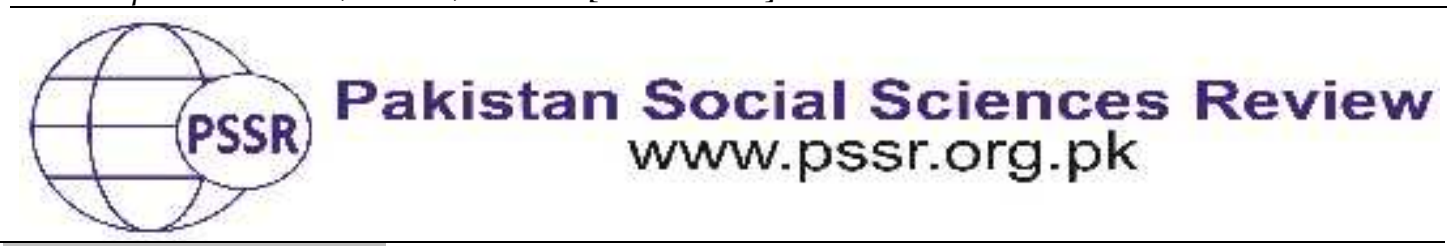

RESEARCH PAPER

\title{
Newspaper's Impact on Education Development in Pakistan: An Analysis
}

\author{
Irum Fazal ${ }^{1}$ Dr. Saifullah Khan ${ }^{2}$
}

1. Public Relations Officer, Federal Urdu University of Arts, Sciences \& Technology, Karachi, Sindh, Pakistan

2. Media Relations Officer, State Bank of Pakistan, Karachi, Sindh, Pakistan

\section{PAPER INFO ABSTRACT}

\section{Received:}

August 17, 2020

Accepted:

September 05, 2020

Online:

September 30, 2020

Keywords:

Educational

Institutes,

Education,

Newspaper,

Print Media

\section{Corresponding}

Author

erum.fazal@fuua

st.edu.pk
The main purpose of this study is to describe news paper's impact on education development and here it can improve educational system. Newspapers have an important role in print media because they contain latest information regarding every field and subject. They have Material for the students of various subjects including Science, Social Science, Commerce and Business Administration.No one can deny the importance of newspapers in 21 ${ }^{\text {st }}$ century.Many educational institutes have libraries where teachers as well as a large number of students get benefit from newspapers on daily basis. In universities, students use authentic newspapers as a reference in writing their research studies It can enhance the knowledge, abilities and skills. It is qualitative research based on literature review and survey protocol to collect date and the data were analyzed on the basis of literature review and survey results. It is concluded that the use of newspapers in academics is very helpful and it increase the ability of the students from school to university level. Some recommendations are given in the end of the study.

\section{Introduction}

As technology progressed, communication and its means has changed rapidly. For a time, in past people were given information by pasting posters on the walls or preaching with musical drums. After passing the time Printing presses came, and newspapers began to be published. Time took another turn, and then radio and TV began to disseminate information to the common man. But world of the internet provided opportunities for the common man to communicate his message to other people without any hindrance (DeFleur et al., 2010).

In earlier times, communication and its means remained in the hands of certain people. Newspapers, according to their policy, forwarded news or 
information. Then the same thing started for radio and TV. Newspapers give little space to education, health, and other critical social issues in addition to political and crime news, while the number of newspapers, radio, or TV can be counted on the fingers of a particular sector which dedicate space or time such as education, health, etc. Newspaper articles, columns, and news have always been used to improve education quality and guide students. The importance and usefulness of a newspaper cannot be denied, which can be kept at all times and used for a long time. (Shamsuddin \& Parveen, 2016).

Reporters, correspondents, and traditional news outlets work to provide news for newspapers. but in the current era and with the flood of technology, everyone wants to be a social media reporter and publisher. In this situation, false, unverified, and, agenda based news and videos on social media have increased exponentially. At the moment, apart from books, newspapers are the most important source of authentic information because it is published after confirmation through valid sources. If newspapers are used in schools, colleges, and universities, it provides students with the opportunity to specialize in a related subject, such as politics, public relations, commerce, law, and more in the United States, England, and many other developed and developing countries. Students of different subjects are also taught in their class with newspaper columns, news, and articles. Whether students are studying international affairs or learning a language, newspapers have always played a valuable and helpful role in learning these disciplines (Obe, 2008).

Education System of Pakistan is very poor Media is forth pillar of the states so Education news published in news paper change the status of educational system and influence on Government policies to reduce the problems related in this field (Benz, 2016).

\section{Literature Review}

Print media is a collective term for media printed on paper and its two main parts are newspapers and magazines but it also includes outdoor billboards, transit posters, the yellow pages, and direct mail. Print media is important because it creates credibility. Investing in printed material signals to customers that customers are serious about their business and they offer a worthwhile product or service. Despite the fact that many companies are now spending less on print than they have done in previous years that are no reason to think that the form of media is any less important. Print media is a form of communication that comes in many different types. Messages can be sent out and printed on fliers, in newspapers, billboards and magazines. Once the pieces are printed, they are distributed to their proper audience.

Main characteristics of print media are that Newspapers are the most common printed mass media and it must get into the hands of the customer, the person who reads the material and responds it properly. (King, 2004) 
Printed media has shaped the way we learn, think, and act in modern society. Yet it all began simply. Ts'aiLun, a Chinese official, is attributed with the invention of paper in A.D. 105. In 1880 the halftone process was developed, allowing for the first photo to be printed in a range of full tones. (Ahuja, 2016)

\section{Newspapers History}

The history of written news dates back to the Roman Empire around 59BC. Back then, Rome was the center of the western world and was the hub of innovation -- from grid based cities to the invention of concrete, Rome was leading the way. Most historians credit the birth of the regular written news updates to the Romans. Acta Diurna (which roughly translates to daily public records) which was hard carved news on stone or metal sheets, covering politics, military campaigns, chariot races and executions, was published daily and posted by the government in the Roman Forum. The Acta which was originally kept secret, was later made public by Julius Caesar in 59BC (Canboy, 2004).

In 17th century in Europe Johann Carolus published the first newspaper called 'Relation aller Fürnemmen und gedenckwürdigen Historien' (Account of all distinguished and commemorable news) in Germany in 1605. You can access some of the digitized versions from 1609. Europe was the hub of printed newspapers in the 17th with quite a few of them starting operations in German, French, Dutch, Italian and English soon after (Biggs, 2002).

The first newspaper to be printed in India was the Hicky's Bengal Gazette in 1780 from a printing press in Calcutta. (Otis, 2018)

Newspapers have been integral to society in recent history and have had a significant effect in shaping our political views. The initial newspapers were expensive and hence read only by the privileged few. The rapid evolution of the printing press brought down the costs of newspapers and helped print a lot more copies at much lower costs (Dominick, 2008).

With the advent of advertising in the 19th century, the cost of newspapers fell significantly and was well within reach of a much wider population. Since then, print media has been growing leaps and bounds and has been an integral part of all of our daily lives. As the circulation grew, so did the ad revenues. These were the heydays of print media -- they were the innovators in using illustrations and images in storytelling, in using telegraph and telephone for rapid sourcing of news from across the world, and setting up widespread distribution channels to reach their audience. Most of the publications were hugely profitable and owned by wealthy individuals who used these mediums to spread their political views.(Dominic, 2008)

The American newspaper business as we know it was born on September 3, 1833, when a twenty-three-year-old publisher named Benjamin Day put out the first edition of the New York Sun. Whereas other papers sold for five or six cents, the Sun 
cost just a penny. For revenue, Day relied on advertising rather than on subscriptions. Above all, he revolutionized the way papers were distributed. He sold them to newsboys in lots of a hundred to hawk in the street. Before long, Day was the most important publisher in New York (Dominic, 2008).

Newspapers have faced competition from other media vehicles in the past. First, In the 1920s and 30s, when radio adoption was growing and organizations started broadcasting news over radio transmission. News over radio was almost immediately available rather than waiting for the next day (Defleur. 2006).

And then, in the 50s when television was a popular device in western homes and became the primary medium to influence public opinion. The news formats on television were a lot more engaging when compared to print or radio. The concept of primetime was invented and people were glued to their television sets between 8pm - 10pm to catch the latest political, sports and weather updates in their country, and across the world (Defleur, 2006).

While both these mediums did have an impact on newspapers initially, print didn't face any existential threat from either of them. In fact, newspaper circulation continued to grow as television got more popular and they were largely considered parallel media rather than direct competition.

However, the last 20-25 years have not been that accommodating to print media in general. The rapid rise of digital media on the back of the internet and smart phone penetration has had devastating effects on newspapers worldwide. The graph below tells the sad tale of newspaper firms in the US, and this continues to be the story almost in every country across the world.

\section{Newspapers in Pakistan}

There are about more than 1000 newspapers published in Pakistan in different languages. Newspapers and magazines are published in 11 languages; most in Urdu and Sindhi, but English-language publications are numerous. Most print media are privately owned, but the government controls the Associated Press of Pakistan, one of the major news agencies. Herald Publications normally known as Dawn Group of Newspapers, the company was founded in 1941 by Mohammad Ali Jinnah. Its flagship publication, the daily Dawn, was first published in 1947 from an already independent Pakistan. The daily Pakistan Observer is one of the largest circulated English newspapers of Pakistan, being published simultaneously from Islamabad, Karachi, Lahore, Peshawar and Quetta. Daily Imroze (Urdu: $\quad$ ) is an Urdu language newspaper in Pakistan published daily from Karachi. This is one of the oldest newspapers of Pakistan that originally started publishing from Lahore in the newly independent Pakistan soon after 1947.The Daily Jang is an Urdu newspaper based in Karachi, Pakistan. It is the oldest newspaper of Pakistan in continuous publication since its foundation in 1939.Nov 17, 2019Jang is the top daily newspaper with a circulation of 850,000. 
Nawa-e-Waqt holds second place with 500,000, followed by Pakistan $(279,000)$, Khabrain $(232,000)$. (www.pressreference.com)

Freedom of the press in Pakistan is legally protected by the law of Pakistan as stated in its constitutional amendments, while the sovereignty, national integrity, and moral principles are generally protected by the specified media law, Freedom of Information Ordinance 2002 and Code of Conduct Rules 2010 (www.pressreference.com).

\section{Education System in Pakistan}

Education is the straightforward procedure of learning and knowing. It isn't limited to the schools as it were. Training begins from the mother's lap. Guardians and family instill great habits and make independent residents out of their kids, Home is called first school of the yo0ungsters, however the proper training begins from the school, where they are instructed, how to act and comprehend what is happening around them. The foundation of every state is the education of its youth.

The circumstanced in Pakistan, in the same way as other developing nations, isn't empowering. The low enlistment rates at the essential level, wide variations among locals and gender discrimination, absences of prepared instructors, lack of appropriate showing material and poor physical framework of schools demonstrates the lackluster showing of this area. Middle class go to more reasonable private organizations and poor people ones are abandoned who at that point join the administration establishments with poor instructive offices. The result of this class distinction is that English medium schools understudies learn least about Islam yet they accumulate sound information on outside world. Aside from the previously mentioned instructive frameworks, another framework is likewise being run i.e. theological schools framework giving kids exclusively with strict training. What's more, no accentuation on current investigations, delivering an age that thinks well about religion however is denied of fundamental present day instruction.

The training status in Pakistan isn't steady since its foundation. The most compelling motivation why Pakistan's falling a long ways behind numerous nations that were established some place close to the period in which Pakistan was framed, is its low education rate, I.e. poor instruction framework (Benz, 2016).

Literacy rate of Pakistan is almost around 58\% where the essentials for being termed an educated person are that you able of reading and writing ( $34 \%$ approx.). Which is not good sign, with a result that more than half of the literate ones are also not educated in a completely proper way.(Ismat and Ashraf, 2018)

Education is well though-out as the most inexpensive shield of any nation. Be that as it may, the down trodden state of instruction in Pakistan bears a plentiful declaration of the way that can't safeguard its own part. In spite of the fact that 74 years have been passed and 23 approaches and activity plans have been presented at 
this point the instruction area is hanging tight for an appearance of a friend in need. The legislature of Pervaiz Musharraf put vigorously in instruction division and that time saw an unmistakable positive instructive change in Pakistani society. Presently days, the financial circumstance in Pakistan is under pressure. The education system of Pakistan is grounded on unsatisfactory lines. Education medium is extremely diverse in both, public and private sector. This forms a category of inequality among people isolating them into two different segments (Nadewala, 2019).

\section{Media Helps to Develop the Education}

The media education has become more important in the training of the teachers; the teachers working in the field of education should not stop with them. Other areas are associated and must be made profound to the needs of young people, such as caregivers or journalists, producers and broadcasters, and all other media professionals. Taken as a whole, the media makes available to the individuals, the possibility of getting familiar with the culture of others, the media culture, the family culture, and the school culture in a spirit of dialogue (Frau-Meets, 2006).

This is what is to be emphasized upon understanding the role of media in the development of education, whose purpose is to deal at the same time with the means to educate others to media and to educate oneself to media, as part of lifelong learning. It recommends the opportunity of a double approach for the user, sometimes in a learner position, and sometimes in a teacher position (Frau-Meigs, 2006).

In our country, the public and private sectors have played a vital role in education sector because the achievements of education do not get the place they deserve in the mass media. The importance of mass media has been shown in many areas and as a result will play an important role in increasing literacy rate (Nasir, 2013).

\section{Some Successful Educational Program through Newspapers}

In this regard, it is important to mention an essential and successful educational program in educational institutions in the South African country of Uganda named "Newspapers in Education (NIE)". According to the program, Ten Ugandan Schools were given the same curriculum in which students in each class were required to read a daily newspaper, after which they would receive up-to-date information from the newspaper about the subject matter. According to the results of the program, the students' knowledge increased tremendously, and they improved their grades and also developed a competitive attitude (Namata, 2010).

Nola KortnerAiex, author of "Using Newspapers as Effective Teaching Tools", notes in her book that reading a newspaper changes students' mental abilities. This slow but steady change widens the horizons. One chapter of this book discusses in detail why newspapers are necessary for education, the main points of which are as follows: 
1. Newspapers promote reading habit.

2. Changes around the world provide an opportunity for both teachers and students to think, understand and discuss.

3. Students have the opportunity to learn new things.

4. There is a connection between the class room and the world.

5. Vocabulary increases.

6. Students' perspectives change.

7. There are different ways of saying and explaining point of view for the students (Kossack, 1987).

The process of teaching and educating students through newspapers continues around the world, including in both developed and developing countries. Launched in the 1980s in the United States, the "newspaper-assisted education" program is still being used today in one form or another in education payments around the world. About 600 newspapers were used during the teaching in the institutions. Three million students and 90,000 teachers benefited from this program in a single year (http:www / / educationworld.com).

"Newspapers Are for Kids, Too!", there was another attempt in which teaching was done in primary schools with the help of newspapers. The program was designed to connect students, parents, teachers, and classrooms with the use of newspapers to teach social sciences, arithmetic, language, and other subjects. Parents were also included in that program. The children took great interest in it and gave excellent results in the examination (Hermann, 1981).

Rhoades and Rhoades (1985), an educationist, said in his research that teachers can help students to develop their creative thinking through newspaper through games. He tried to explain through an example that from newspapers, remove all headlines and paste only one news item in the classroom and ask students what the headline will be or do it in such a way that a meaningful headline is taken out and different news is given, and the children are asked which headline will be attached to which news and what is the reason for its attachment. It can also be useful for teaching writing and improve language skills (Rhodes and Rhodes, 1985).

Newspapers are used to teach English in the African country of Rwanda. A regular program called "Rwanda Teachers Education Program", (RTEP) has been launched in Rwandan schools. According to Dr. Joseph Olzaczi, Rwanda's program director, English language skills can be enhanced through newspapers. This program is running successfully in Rwanda (Yeatonet al., 1986). 
Similarly, Joseph Rutakanize, in-charge of the "Rwanda Education Board", (REB), Science Unit, says that newspapers' main purpose is to provide authentic news and information to the people, including students. A few examples can be given to illustrate this. Teachers have selected some articles for teaching according to their subject matter. They say that newspapers contain relatively up-to-date information on textbooks of almost every subject which, after acquiring it, dramatically enhances the abilities of the students (http://www.onestopenglish.com).

In 1981, Hamrick wrote a 60-pages book, based on the same above mentioned teaching methods. It was explained in it that how newspapers can be used to teach a variety of subjects. It states that students can be taught different subjects and skills with the help of newspapers and through different exercises in the classroom, the students 'abilities can be tested and enhanced (Hamrick, 1981). Authoritative newspapers, whether in print or online, are extremely helpful in promoting education. Authoritative newspapers provide up-to-date information on each subject and play an important role in language learning and accuracy. In the present era, students or teachers in any country living in any part of the world can read newspapers on daily basis through the internet. Newspaper articles link their curriculum to the current era.

Enmy Ntiguirwa, a teacher of English and Swahili at GS Marie Reine Ruramba, District, Nyamagab, states that the use of newspapers in teaching is essential and necessary because it solves problems around the world under the roof of a classroom. He says that in schools where daily writing and reading exercises are conducted through newspapers, the academic abilities of the students are much better than those of the students of other schools. While newspapers publish news on daily events, crime, health, and other important events, there is also news on sensitive, serious, and most important topics such as education. In highly circulated news paper a separate reporter called a BEAT reporter is assigned for particular area such as education, health, crime etc to highlight and file the news. He is well versed in his field and aware of its strengths and weaknesses. In some newspapers, the same reporter files news on two or more topics. However, in both cases, it is the reporter's responsibility to present the problems in the field of education through his talent and news. If the government and the concerned agencies are sincere, such news will help them to solve various problems. In this way, it can be said that the educational information in the newspapers play an important role in the promotion of education because the news in it makes the government aware of the shortcomings of this sector and not only helps them to solve these problems. With the help of these news suggestions for solutions are obtained but also help in policymaking (Nawaz, 2006).

\section{Newspaper, Library and Educational Institutions}

According to a study conducted in January 2019, there are about 2 lac public and 6.8 million private schools, more than 5,000 colleges, and according to a study 
conducted in April 2020, there are 188 public and private universities in Pakistan (Benz, 2014). Most educational institutions have libraries where newspapers come regularly and are used by a large number of students and teachers. $50 \%$ of the total libraries in the country belong to some educational institute. However, the number of libraries is very small in proportion to the country's population, and the trend of reading books and newspapers is also declining day by day while despite the rampant use of the internet and mobile in developed countries. The usefulness of libraries and the tendency to read books has not diminished. This is mainly due to the fact that the literacy rate in these countries is 80 to 99 percent, as in the United States and the United Kingdom in 2019, the literacy rate was 99 percent, and in China, it was 96.36 percent, and in a less developed developing country like Bangladesh, it is 74.04 percent. In comparison, the literacy rate in Pakistan is still $58 \%$. In countries where the literacy rate is better, the rate of people's reading newspapers will also be higher (Khurram, 1999). In addition, in developed countries, students are accustomed to reading libraries, books, and newspapers from the primary school level. In most developed countries, newspapers are being used for teaching and learning, and this experiment has been very successful for many years because the curriculum has specific topics while the newspapers have modern information about these subjects. which is also important to know for each student. On the contrary, in our country, the same worn-out curriculum is being taught year after year, which reduces the students' mental capacity instead of increasing it. Students have to pass the equivalent examination of their education when they go abroad and qualify for employment abroad.

The research revealed the successful use of the newspaper in teaching in some schools and coaching centers in Karachi, such as during a visit to the A-Class Institute in Surjani Town, Karachi, English Newspaper is given to the students and asked to translate or summarize any one topic or paragraph on daily basis. It aims to increase translation skills and provide information to children. Teacher Salman, who was there, told us that many English words that children do not use in their curriculum or at home, they learn with the help of newspapers and use in daily life. Therefore, it cannot be believed that there is a rush to provide news in a hurry, which strikes a chord with the realism of the news. If the curriculum is linked to the information given in the newspapers, it will enable the students to cope with the changes taking place in the world after coming into practical life (http:/www.abc.gov.pk).

Diana Nawatt is in charge of all the teachers at the Mother Mary Complex, an educational institution located in Africa. In their view, the learning process should be $70 \%$ through practical exercises, while only $30 \%$ should be theoretical education. These practical exercises can be developed through various teaching methods through newspapers such as Teaching Aids, which include real-life stories. He says that newspapers can be used to teach various subjects such as English, Science, Geography, Business Administration, Sports, Art etc (Buzarna, 2018). 
In modern times, research and creation are happening very fast. Changes are happening on daily basis all over the world. In these situations, it is important for students to be equipped with the latest information. Newspapers are printed on paper used to keep the students connected with time. This facility is now available through the internet, where newspapers have their archives. It makes easier to work on any topic for the students. According to a BBC study, in modern times, the convenience of newspapers and archives has brought teachers and students together in the outside world. Now any question that arises in the class can be found immediately (Wimmer \& Dommick, 2008).

In fact, in modern times, the need for authentic newspapers and modern technology in the classroom has increased. We now have to make it part of the classroom because most media outlets provide so much unverified information that we need authentic newspapers, whether they are in print or on a web page all the time so that everyone gets up-to-date information on the subject and topic.

\section{Material and Methods}

This article has been prepared in the style of descriptive research. In this method of research, the subject is described in all its details and nuances and every effort is made to clarify all the important points related to the subject in order to complete and present this statement in every respect Qualitative and Quantitative research method is used to prepare this article.

Survey method is also used to justify the research.

The survey includes librarians of 50 educational institutions (schools, colleges and universities). Answers to 10 different questions about the arrival of students in the library from teachers and principals, the trend of reading newspapers, the help of newspapers in classroom teaching and the use of newspapers in education and research and the role of educational news in promoting education. The analysis is presented with the help of their feedback.

\section{Survey Conducted To Know the Importance of Newspaper}

In this regard, a survey was conducted in which librarians, teachers, and principals of 50 educational institutions (schools, colleges, and universities) located in different districts of Karachi were asked to answer 10 questions. On the basis of which, newspapers use for teaching and research in educational institutions and the tendency of teachers and students to study and seek help from it was analyzed.

Question No. 1: $\quad$ Does your educational institution have a library?

Question No. 2: $\quad$ Apart from Urdu language, do other language newspapers also come in the library? 
Question No. 3: $\quad$ Do teachers and students read newspapers regularly in the library?

Question No. 4: $\quad$ Are the newspapers coming to the library sufficient in terms of the number of students?

Question No. 5: $\quad$ Are these newspapers easily available in the library for the students?

Question No. 6: $\quad$ Do teachers in your educational institution use newspapers in the educational process?

Question No. 7: $\quad$ Do students use newspapers in assignments and other educational processes?

Question No. 8: $\quad$ are newspapers given to students for reading during academics in the classroom?

Question No. 9: $\quad$ Does educational news promote education?

Question No. 10: Does educational news affect the education policy?

\section{Results and Discussion}

Newspapers are very important as a teaching tool for students as it not only provides authentic and factual news but also provides students with information and the use of English and other languages. Newspapers offer a variety of perspectives, from business to lifestyle trends, as well as world events. Sharpen students' thinking skills. Providing study materials related to students' lives increases their interest and motivation. In addition, newspapers prepare students for active citizenship in a democracy and increase teachers' interest in new teaching techniques.

Newspapers contain more information than textbooks that can generally improve student performance. Through the newspaper, students improve their pronunciation and become better users of news and language. When teachers use newspapers in the classroom, it helps students see things in a larger range. And it improves their critical thinking skills because they cover a lot of things in one thing.

Newspapers must be used as teaching aids because they bring real-world problems into the classroom. Newspapers can also play a role in increasing literacy. Schools that use newspapers on a daily basis, develop reading, writing, listening, and speaking skills that are fundamental to students' academic performance. Newspapers are helpful at every level of education. If early students start using newspapers, they will become more aware of the passage of time and will reach higher levels of ability and competence. The newspaper is a powerful tool for 
bringing about socio-political change, working as students to better understand and express students' rights and responsibilities as citizens.

Newspapers can be a great tool for teaching students, how to present a project through newspapers. Newspapers inform students about events and problems happening around the world, which enhances their decision-making ability. It can be said that newspapers are very helpful in education because every page and section of them have completely new information for teachers and students. Therefore, using newspapers as teaching aids, especially as a tool to promote a culture of reading where the government and other stakeholders have worked hard, has enhanced the skills of teachers and local education leaders.

Table 1

Results show the answers of questions has been surveyed during study

\begin{tabular}{ccccc}
\hline Question No & Yes & No & Yes (\%) & No (\%) \\
\hline 1. & 35 & 15 & $70 \%$ & $30 \%$ \\
\hline 2. & 30 & 20 & $60 \%$ & $40 \%$ \\
\hline 3. & 32 & 18 & $64 \%$ & $36 \%$ \\
\hline 4. & 25 & 25 & $50 \%$ & $50 \%$ \\
\hline 5. & 32 & 18 & $64 \%$ & $36 \%$ \\
\hline 6. & 35 & 15 & $70 \%$ & $30 \%$ \\
\hline 7. & 30 & 20 & $60 \%$ & $40 \%$ \\
\hline 8. & 40 & 10 & $80 \%$ & $20 \%$ \\
\hline 9. & 30 & 20 & $60 \%$ & $40 \%$ \\
\hline 10. & 33 & 17 & $66 \%$ & $34 \%$ \\
\hline
\end{tabular}

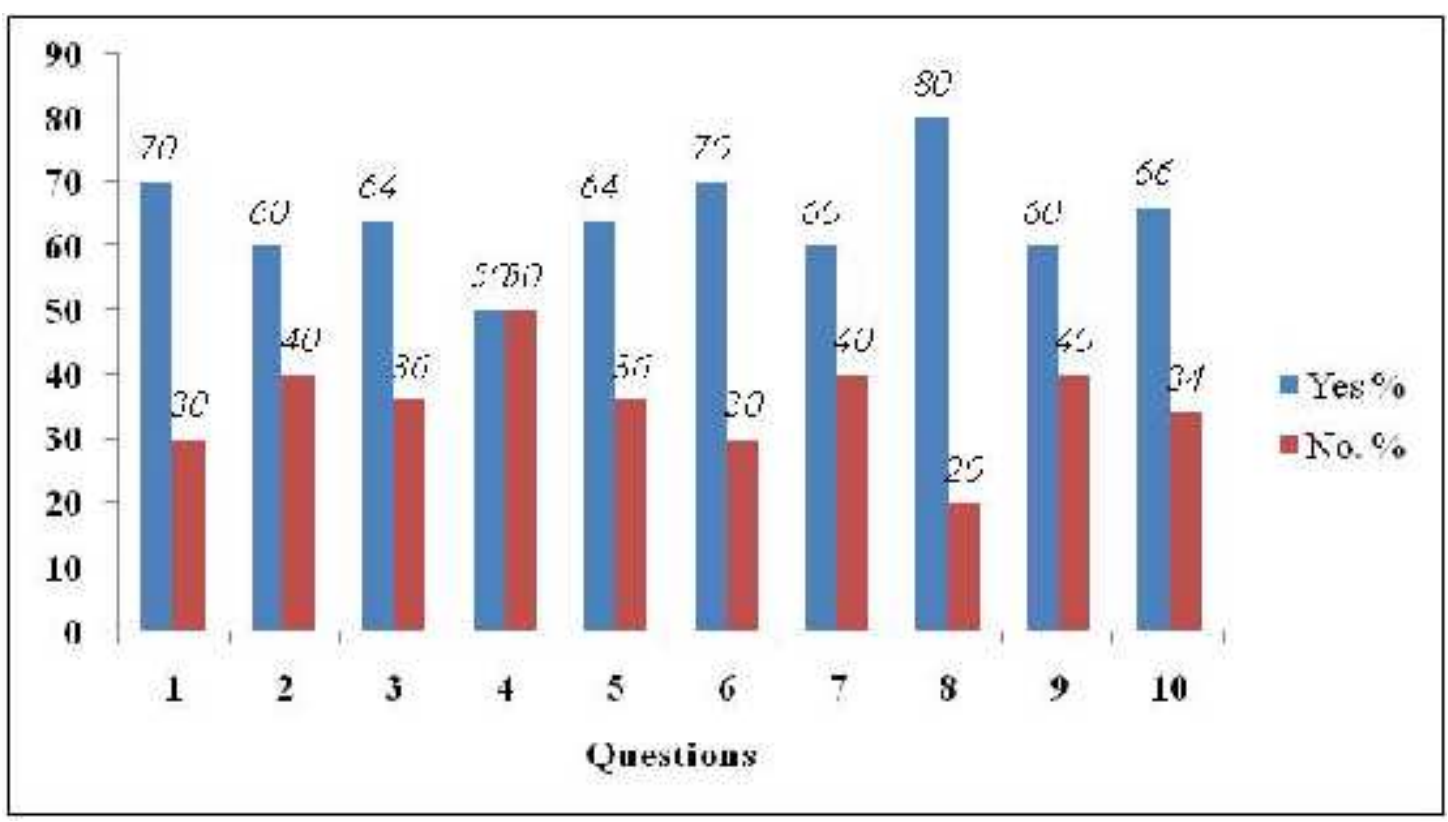

Fig 1 show the result of survey 
The results (Table 1) of the survey revealed that $70 \%$ of the educational institutions have a library, while $30 \%$ of the educational institutions do not have a library at all. In response to a question, $60 \%$ of the respondents said that newspapers come to the library in addition to the Urdu language, while $40 \%$ said that only Urdu language newspapers come to the library. In response to other questions, $64 \%$ said that teachers and students come to the library regularly to read newspapers, while $36 \%$ said they do not come to the library regularly. $64 \%$ said that newspapers are easily available in the library While $50 \%$ said that is not enough. $64 \%$ said that newspapers are easily available in the library, while $36 \%$ said that they have to search or ask the librarian. $70 \%$ said that teachers use newspapers in the educational process, while $30 \%$ said that teachers teach according to a specific curriculum. $60 \%$ said that newspapers are given to students for reading while teaching, while $40 \%$ said that they are not given. $80 \%$ said that students use newspapers in an assignment and other educational processes, while $20 \%$ said that students do not use newspapers. $60 \%$ of students said that educational news promotes education, while $40 \%$ said that educational news does not change the situation of education. $66 \%$ said that education news affects education policy, while $34 \%$ said that news related to the education sector does not affect education policy at all (Fig 1).

The survey revealed that most public and medium-sized private schools and colleges do not have libraries, nor do they provide newspapers for teachers and students. However, there is a library in good quality, high level private schools where each class has a specific period to go to the library, where children not only benefit from newspapers and books related to their curriculum but also benefit from recreational books and newspapers. Most school's libraries usually have two newspapers, one in Urdu and the other in English. These newspapers are easily accessible to students, but they cannot take them to their classroom or home. Teachers, however, are used to teach through newspapers. As a whole, it has been concluded that in big cities like Karachi, where the literacy rate is highest, only $70 \%$ of educational institutions use newspapers as part of their teaching and learning. Most newspapers were used in universities. University libraries also have English, Urdu, Sindhi, and other language's newspapers from 12 to 25 and a large number of teachers and students use them to prepare educational assignments and dissertations at the graduate, Masters, M.Phil., and Ph.D. levels While in classes, teachers often use newspapers to acquire up-to-date information on various subjects. The results of the survey were astonishing and showed the special interest of students in reading newspapers, even though they were not accustomed to it from the primary level, but when newspapers were readily available in the library at the university level, they used them to improve their academic ability and achieved success. This shows that in developing countries, such as Pakistan if newspapers are used at the school level, the habit of reading in students must be developed and their academic performance also will be increased significantly. 


\section{Conclusion}

Newspapers are being used successfully for teaching in educational institutions all over the world, even in modern times. Surprisingly, in a modern country like the United States, the trend of reading books and newspapers has increased rather than decreased in the age of digital development. The research has shown that the use of newspapers in teaching exponentially enhances the abilities of not only teachers but also students. As their knowledge of each subject becomes more extensive and updated, their intelligence also increases compared to other students. In developing countries, although newspapers are effectively used as references for research at the university level, the use of newspapers at the school and college level is almost non-existent. According to them, they do not have the latest information related to their subjects, which makes it difficult for them to succeed in practical life. It is very disappointing situation that Education Reporters are not performing their duties in proper way.

\section{Recommendations}

If regular use of newspapers in developing countries like Pakistan's educational institutions, especially in schools, is done in teaching, it will greatly improve the education status and also increase the intelligence of the students. Similarly, if the education reporters perform their duties better and highlight the shortcomings in the education sector through their news, giving suggestions to guide the government and policymakers, it will also help significantly in promotion of education. So Newspaper should be compulsory part of syllabus from schools, college to university level. 


\section{References}

DeFleur, L. MELUIN. \& Dennis, E. Everette, (2010). Understanding Mass Communication- Fourth Edition, MC GrawHilPubisher.pp 234-375.

Shamsuddin, M. and Parveen, A. (2016). Sociology and Communication, Department of Mass Communication, University of Karachi. P- 265.

Obe, J. (2008). Introduction to Mass Communication Mac III", Publisher: National Open University of Nigeria. pp 121-122.

Benz, Andrease, (2016). Education for development in Northern Areas, Oxford Press, P110

King, Andrew\& Plunkett, John,(2004). Popular Print Media,1820-1900,volume III, Routledge Press, London and New York, pp 509-515

Ahuja, Charanjit \& Hitesli, (2016), Print Journalism, partridge publisher, India, P 2026

Conboy, Martin, (2004). Journalism: A Critical History, Sage Publication London, New Dehli, P 1-9

Briggs, Asa\& Burke Peter, (2002), A social History of the Media from Gutenberg to the internet, Polity Press, USA, P 1-13

Ots, Andrew, (2018). Hickey's Bengal Gazette (The untold story of India's first newspaper), Westland Publications. P-1

Dominick, R. Joseph, (2008). The Dynamics of Mass communication(Media in the middle age, $7^{\text {th }}$ edition),McGraw Hill Publication, USA, p-88

Defleur, L. Meluin \& Dennis, E, Everlette, (2006), Understanding mass communication (4th Edition), p-84

Benz, Andrease, (2016). Education for development in Northern Areas, Oxford Press, P110

Ismat, Hafiza Iqra \& Ashraf Azeem, Mohammad, (2018). Study of Current situation of A:Eduation and Development of Pakistan, Education and Literacy in Pakistan.

Nadewala, Nadia, (2019). The real story: Pakistan's Education Crises, Wilson Center

Frau-Meigs, D. (ed), (2006). Media Education:A kit for teachers, students, parents and professionals http//www.unesdoc.pg/images/0014/00149278e.pdf 
Nasir, M. (2013). Role of Media in a developed society, Interdisciplinary journol of Contemporary research in Business 5(2) pp 407-415

Namata, W. (2010).Newspapers as tolls of Literacy in Uganda (A case study)", Publisher: Department of Media and communication, University of Oslo, Norway.

Kossack, S. (1987). Use the news. NIEWEEK, AWPA: Resources for reading," Journal of Reading. pp. 552-554.

Hermann, P. (1981). Newspapers are for kids, too! A newspaper in education handbook for parents [and] Eddy Torial brings big news for small people (fun activities with the newspaper for kids). pp. 23-24.

Rhodes, L. \& Rhodes, G. (1985).Using the daily newspaper to teach cognitive and effective skills."-clearing house, 59(4): 162-165.

Yeaton, C. S. and Braeckel, K. T. (1986). A salute to our Constitution and the Bill of Rights: 200 years of American freedom. Using the newspaper to discover how the Constitution and Bill of Rights work. p 11.

Nawaz, M. (2006).Mass Communication, An Introduction to Information Revolution, Theories, Skills and Practice, Higher Education Commission. pp 170-171.

Benz, A. (2014). Education for Development in Northern Pakistan, Oxford Press, pp 110111.

Khurram, M. A. (1999). The Formation of the National Education System, Modern Theory and Practice, Rahbar Publisher, Urdu Bazaar, Karachi.pp 427-428.

Buzarna, T. \& Alina, N. L. (2018). The Advantages of Authentic Material in the ESP/EFL, Classroom: Newspapers", Ovidius, University of Constant, Faculty of Journol, Ovidius University Annalas, Economics, Science Series Volume XVIII Issue 1.

Wimmer, R. and Dommick, J. (2008).Mass Media Research, Columbio University.pp 306-307. 